FINAL VERSION

19 July 2011

\title{
The Norwegian Shareholder Tax Reconsidered ${ }^{\mathrm{a}}$
}

\begin{abstract}
In an article in International Tax and Public Finance, Peter Birch Sørensen (2005) gives an in-depth account of the new Norwegian Shareholder Tax, which allows the shareholders a deduction for an imputed risk-free rate of return. Sørensen's positive evaluation appears as reasonable for a closed economy where the deduction for the imputed return is capitalized into the market prices of corporate shares. We show that in a small open economy where no capitalization occurs, the Norwegian shareholder tax is likely to leave the distortions caused by the corporate income tax unaffected, and to add new distortions to shareholders' portfolio decisions.
\end{abstract}

Key words: Tax neutrality, open economy, shareholder taxation, corporate-personal tax integration, small firms

JEL code: $\mathrm{H} 24, \mathrm{H} 25$

Jan Södersten (corresponding author)

Department of Economics, Uppsala University

jan.södersten@nek.uu.se

Tobias Lindhe

Uppsala Center for Fiscal Studies (UCFS)

Department of Economics, Uppsala University

tobias.lindhe@telia.com

\footnotetext{
${ }^{\curvearrowleft}$ We are grateful to Steve Bond, Martin Jacob and Michael Riis Jacobsen for useful comments.
} 


\section{Introduction}

In 2006 the Norwegian government introduced a new and innovative system for taxing dividends and capital gains. The new approach is to exempt dividends and capital gains corresponding to a normal rate of return from tax and to levy a full tax - equal to the personal tax rate on income from capital - on any excess returns.

The new rules replaced the earlier imputation system which was introduced in the beginning of the 1990's to eliminate tax distortions on corporate investment and financing decisions. The Norwegian imputation system effectively exempted income from corporate shares from tax at the personal level, and because of this, the total tax levied on the return to corporate investment was the same irrespective of the sources of funds used by the firm. At the same time, this also meant that capital income was taxed at a lower rate than the top marginal tax rates on labor income, creating a strong incentive for owners of small closely held corporations to report highly taxed earned income as leniently taxed income from capital. Special income-splitting rules were set up to prevent such income shifting behavior, but over the years the Norwegian tax authorities found that these rules failed their purpose to an ever increasing extent. The chosen solution to this tax policy dilemma was to abandon the imputation system in favor of the new shareholder tax.

An in-depth account of the new system and its implications has earlier been given in an article in International Tax and Public Finance, written by the chief architect of the reform, Peter Birch Sørensen ${ }^{1}$. Sørensen concludes that the new rules make the tax neutral with the respect to firms' investment and financing decisions and to shareholders' decisions to realize capital gains. As any excess return is double taxed - through the combination of the corporate income tax and the personal tax on income from capital - the incentive for income shifting is likewise considerably reduced.

Sorensen's positive evaluation appears as reasonable for a closed economy where the deduction for the imputed risk-free rate of return is capitalized into the market prices of corporate shares. However, Norway is a small open economy with an extensive foreign ownership of corporate shares. During 2006-2009, for example, foreign investors on average accounted for 56 percent of the market value of the Oslo Stock Exchange, compared to a mere

\footnotetext{
${ }^{1}$ Sørensen (2005). Sørensen’s article was written before the implementation of the new system on January 1, 2006, and is based on a 2003 report from a government-appointed expert committee.
} 
12 percent for household investors (including indirect ownership through mutual funds). ${ }^{2}$ There are reasons to believe, therefore, that equity prices and the equilibrium rates of return are determined by foreign investors rather than by the domestic households who are the beneficiaries of the new rate of return allowance. In this article, we demonstrate that, absent capitalization, the Norwegian shareholder tax is likely to leave the distortions caused by the corporate income tax unaffected, and to add new distortions to shareholders' portfolio decisions.

The article is organized as follows. Starting with a closed economy setting, where tax capitalization occurs, Section 2 shows how different rules for taxing dividends and capital gains affect the before tax required rate of return on corporate shares and the cost of capital. The holding period neutrality claimed by Sørensen for the Norwegian shareholder tax is scrutinized in Section 3. Section 4 next explores the case of a small open economy. On the assumption that no tax capitalization occurs and that the before-tax equilibrium rate of return is internationally determined, we compute and compare the after-tax returns received by investors, under different rules for taxing dividends and capital gains. We find that the Norwegian shareholder tax distorts the allocation of savings more (for a given statutory tax rate) than does a conventional tax regime with a realization based capital gains tax.

Section 5 considers the possibility that in small open economies the options to finance investments on the international markets for equity may be unevenly distributed between firms. We extend the mean-variance portfolio model developed by Apel and Södersten (1999) to determine the effects of the Norwegian shareholder tax on the cost of capital for large and small firms. We find that the internationally determined rate of return requirement on large company shares may have a very substantial impact on the rate of return requirement for small company shares. Such a link considerably weakens the effect of the rate of return allowance of the shareholder tax also for small domestically owned companies, and may even imply a detrimental effect on small company investment incentives. Section 6 concludes.

\section{Shareholder Taxation and Before-tax Rates of Return}

To put the Norwegian shareholder tax into perspective, this section of the paper briefly compares how four different regimes for taxing dividends and capital gains determine before-

\footnotetext{
${ }^{2}$ Own calculations, based on data from the Norwegian Securities Registration Centre (Verdipapirsentralen ASA, www.vps.no). The numbers exclude public sector ownership.
} 
tax required returns on corporate shareholdings and the firm's cost of capital. The first of these regimes, Regime 1, assumes that all forms of personal income from capital - including accruing changes in the market value of shares - are taxed at the same rate. This corresponds to the Schanz-Haig-Simons concept of economic income ${ }^{3}$. Though rarely practiced in real world tax systems, accruals taxation is often used as a reference case in tax research. Regime 2 also assumes a uniform tax on income from capital, but differs from Regime 1 by assuming that realized rather than accruing capital gains on shares are taxed. This represents a common system of shareholder taxation, in countries that do not mitigate corporate double taxation at the shareholder level. Regime 3 models an innovative technique suggested by Auerbach and Bradford for eliminating the lock-in effects that plague realization-based capital gains taxation, whereas Regime 4 is the Norwegian shareholder tax.

Throughout this section, the setting is a closed economy where shareholder taxes are capitalized into the market values of corporate shares. As in Sørensen (ibid.), we ignore risk and we assume that the investor requires a return after all taxes equal to the after-tax market interest rate.

Consider a share with an acquisition cost of $M_{0}$ at time 0 , which is expected to have a market value of $M(s)$ at time s. At each instant of time a dividend $D(s)$ is paid. The market interest rate is $i$ and there is a tax on interest income at the rate $\tau$.

Regime 1 assumes, as explained, that the shareholder is taxed at the rate $\tau$ also on dividends and on the accruing changes in the market value of the asset. An investor with a required rate of return equal to the after- tax market interest rate $i(1-\tau)$ and a holding period of $L$ is indifferent to acquiring the asset provided that

$$
M_{0}=\int_{s=0}^{L}\left[(1-\tau) D(s)-\tau \frac{\partial M(s)}{\partial s}\right] e^{-i(1-\tau) s} d s+M(L) e^{-i(1-\tau) L}
$$

By computing $\frac{\partial M_{0}}{\partial L}$ and equating the derivative to zero, we find that the investor is indifferent also to extending the holding period $L$ provided that

\footnotetext{
${ }^{3}$ See Sinn (1987), Chapter 3, for further explanation.
} 


$$
\frac{\frac{\partial M(L)}{\partial L}+D(L)}{M(L)}=i,
$$

that is, the required rate of return before personal taxation is the market interest rate. This neutrality result, which was demonstrated a long time ago by Johansson (1961) and Samuelson (1964), also implies that taxation will not affect the market valuation of the firm's shares ${ }^{4}$.

Regime 2 is a convention system of shareholder taxation, where realized rather than accruing capital gains are taxed, and where the rate of tax on realized gains is set equal to the tax rate on dividends and interest, $\tau$. This means that

$$
M_{0}=\int_{s=0}^{L}[(1-\tau) D(s)] e^{-i(1-\tau) s} d s+M(L) e^{-i(1-\tau) L}-\tau\left(M(L)-M_{0}\right) e^{-i(1-\tau) L},
$$

assuming that the acquisition cost $M_{0}$ is deductible when determining the taxable capital gain.

Computing $\frac{\partial M_{0}}{\partial L}=0$ we now find that

$$
\frac{\frac{\partial M(L)}{\partial L}+D(L)}{M(L)}=i\left(1-\tau\left[\frac{M(L)-M_{0}}{M(L)}\right]\right),
$$

which means that the required pre-tax rate of return is below the market interest rate. The reason for this is that the payment of capital gains tax is deferred until realization without interest. The shareholder hence obtains an interest free loan from the government, equal to the deferred capital gains tax, and this tax debt effectively limits the investor's own investment to $1-\tau\left(M(L)-M_{0}\right) / M(L)$ per unit of market value ${ }^{5}$. The effect of this is also that an investor who expects the market value $M(L)$, and hence the tax debt, to rise over time, may accept a gradually lowered return on his investment. Put differently, there is a tax advantage to holding

\footnotetext{
${ }^{4}$ See Sinn (1987), Chapter 5, for further explanation. Sinn denotes the neutrality result as the JohanssonSamuelson Theorem.

${ }^{5}$ The effects of accelerated depreciation in corporate taxation may be interpreted in a similar way, see Södersten (1982) and King and Fullerton (1984).
} 
on to a corporate share compared to selling and re-investing in the stock market. This is the well-known lock-in effect of taxing capital gains upon realization. ${ }^{6}$

For Regime 3, we consider the scheme for retrospective capital gains taxation suggested by Auerbach (1991), and further developed in Auerbach and Bradford (2004). The scheme imposes a tax upon realization, equal to $\left[1-e^{-i \tau L}\right] M(L)$, where, as before, $M(L)$ is the market value of the share when sold at time $L$, and $\tau$ is the capital income $\operatorname{tax}^{7}$. This "effective" tax rate, $\left[1-e^{-i \tau L}\right]$, therefore depends on the holding period, $L$. The scheme also subjects intermediate distributions (i.e. dividends, in this case) to a corresponding time-dependent effective rate, which is $\left[1-e^{-i \tau s}\right]$, at time $s$. We note that the time-dependency implies that the effective tax rate is zero for $s=0$, and equals unity when $s(=L)$ is infinitely large.

For the shareholder to acquire the asset, it must then hold that

$$
\begin{aligned}
& M_{0}= \\
& \int_{s=0}^{L}\left[D(s)-\left(1-e^{-i \tau s}\right) D(s)\right] e^{-i(1-\tau) s} d s+M(L) e^{-i(1-\tau) L}-\left[1-e^{-i \tau L}\right] M(L) e^{-i(1-\tau) L} .
\end{aligned}
$$

Collecting terms, (5) simplifies to

$$
M_{0}=\int_{s=0}^{L} D(s) e^{-i s} d s+M(L) e^{-i L}
$$

Computing $\frac{\partial M_{0}}{\partial L}$ and equating the derivative to zero, we find that

$$
\frac{\frac{\partial M(L)}{\partial L}+D(L)}{M(L)}=i
$$

which means that the investor is indifferent to extending the holding period when the pre-tax rate of return equals the market interest rate. Since the required before-tax rate of return is independent of the holding period, the scheme is holding period neutral, in Auerbach's (1991) terminology.

\footnotetext{
${ }^{6}$ Cf. Auerbach (1991), see also Section 3 below.

${ }^{7}$ See Auerbach (1991), p. 170, and Auerbach and Bradford (2004), p. 961.
} 
For Regime 4, finally, consider the effects of the Norwegian shareholder tax, as presented in Sørensen (2005). The tax is levied on the equity premium on shares, by allowing the investor to deduct an imputed rate of return - denoted a rate of return allowance - against taxable dividends or realized capital gains. The allowance is set equal to the after tax interest rate. Assume first that annual dividends are larger than the allowance, $D(s)>i(1-\tau) M_{0}$. This means that

$$
\begin{aligned}
& M_{0}= \\
& \int_{s=0}^{L}\left[(1-\tau) D(s)+\tau i(1-\tau) M_{0}\right] e^{-i(1-\tau) s} d s+M(L) e^{-i(1-\tau) L}-\tau\left(M(L)-M_{0}\right) e^{-i(1-\tau) L} \cdot(7)
\end{aligned}
$$

Alternatively, the investor may save the allowance until realization, which means that there is an offset of $M_{0} e^{i(1-\tau) L}$ against the taxable realized gain. Hence

$$
\begin{aligned}
& M_{0}= \\
& \int_{s=0}^{L}[(1-\tau) D(s)] e^{-i(1-\tau) s} d s+M(L) e^{-i(1-\tau) L}-\tau\left(M(L)-M_{0} e^{i(1-\tau) L}\right) e^{-i(1-\tau) L}
\end{aligned}
$$

It is straightforward to show that the two expressions (7) and (8) are identical ${ }^{8}$.

Computing $\frac{\partial M_{0}}{\partial L}$ and equating the derivative to zero, we find

$$
\frac{\frac{\partial M(L)}{\partial L}+D(L)}{M(L)}=i(1-\tau),
$$

that is, the pre-tax equilibrium rate of return is the after-tax rate of interest. The rate of return allowance hence eliminates the tax wedge between the investor's after-tax return and the pretax rate of return on corporate shareholdings.

We next turn to the implications of the different shareholder tax regimes for the firm's cost of capital. We limit our interest to Regimes 1, 3 and 4 above, where the pre-tax equilibrium rates of return are constant over time. To focus on the key differences between the regimes, we consider a simple case where the corporate tax rate is $\tau$ and the firm earns a pre-tax rate of

\footnotetext{
${ }^{8}$ In-between cases where the investor uses part of the allowance as an offset against taxable dividends and saves the remainder, including compound interest, as an offset against taxable capital gains yield the same result.
} 
return on real investment, $\pi$, which is constant over time. To determine the lowest acceptable level for this pre-tax return, that is, the firm's cost of capital, we simply equate the expressions for the pre-tax required rates of return on corporate shareholdings as derived above, to the after-corporate tax rate of return, $\pi(1-\tau)$. We then obtain for Regimes 1 and 3 $\pi=\frac{i}{1-\tau}$

which means that the corporate income tax is the sole determinant of the tax distortion to the cost of capital.

For Regime 4 (the new Norwegian shareholder tax, see equation (9) above) and other regimes which effectively exempt equity returns from tax at the shareholder level, we derive

$$
\pi=i,
$$

which means that the cost of capital is independent of tax.

The results derived in this section for the before-tax required rates of return and the cost of capital are summarized in Table 1 below, in each of the four regimes.

Table 1. The Required Rate of Return and the Cost of Capital for the different regimes.

\begin{tabular}{|l|c|c|}
\hline Regime & $\begin{array}{l}\text { Required before-tax rate of } \\
\text { return on shareholdings }\end{array}$ & Cost of capital \\
\hline 1. Accruals based capital gains tax & $i$ & $\frac{i}{1-\tau}$ \\
\hline 2. Realization based capital gains tax & $i\left(1-\tau\left[\frac{M(L)-M_{0}}{M(L)}\right]\right)$ & - \\
\hline 3. Retrospective capital gains tax & $i$ & $\frac{i}{1-\tau}$ \\
\hline 4. Norwegian shareholder tax & $i(1-\tau)$ & $i$ \\
\hline
\end{tabular}

As seen from the first column of the table, the required before-tax rate of return on corporate shareholdings is constant, and is therefore independent of the holding period, for all regimes except for Regime 2, where a realization based capital gains tax is applied. Hence, the Norwegian shareholder tax (Regime 4) meets Auerbach’s definition of holding period 
neutrality (cf. p. 6 above for the definition). Holding on to a corporate share offers no tax advantage compared to selling and re-investing in the stock market. We note that holding period neutrality would be obtained also for a tax regime which effectively exempts both dividends and capital gains from personal tax, as this may be seen as a special case of Regime 1 above. Such a scheme was in effect in Norway during the period 1992-2005, when the imputation system for taxing dividends was combined with the so called RISK-model for taxing capital gains. The RISK-model limited capital gains taxation to that part of the gain which exceeded the shareholder's proportionate share of a corporation's retained earnings. ${ }^{9}$

In Regimes 1 and 3, the corporate tax is the sole determinant of the tax distortion to the firm's cost of capital, whereas the cost of capital is independent of tax in Regime 4, the Norwegian shareholder tax. The explanation to this latter result is that the distortion caused by the corporate income tax is exactly offset by the reduction in shareholders' pre-personal tax required rate of return, shown in the first column of the table. This confirms Sørensen's (2005) claim that the Norwegian shareholder tax is neutral with respect to firms' financing and investment decisions. However, and as emphasized in the beginning of this section, this neutrality result requires that shareholders' taxes on dividends and capital gains are capitalized into the market values of corporate shares.

\section{Holding Period Neutrality - a clarification.}

As shown in section 2 above, the Norwegian shareholder tax meets Auerbach's condition for holding period neutrality in the sense that the required before tax rate of return on equity investment is independent of the investor's holding period. This section further explains the meaning of holding period neutrality for the Norwegian shareholder tax.

Following Sørensen (2005), we may assume that a share with market value $M_{t}$ is sold at time $t$. If $B_{t}$ is the basis of the share for tax purposes and $\tau$ is the capital gains tax, the investor's capital gains tax liability is $T_{t}=\tau\left(M_{t}-B_{t}\right)$. If the transaction is postponed until $t+1$, and assuming that no dividend is paid, the tax liability is then $T_{t+1}=\tau\left(M_{t+1}-(1+i(1-\tau)) B_{t}\right)$ since the basis of the share is stepped up by the after-tax interest rate, $i(1-\tau)$. Combining $T_{t}$ and $T_{t+1}$, Sørensen derives

\footnotetext{
${ }^{9}$ See Andersson et. al. (1998), pp. 96.
} 


$$
T_{t+1}=(1+i(1-\tau)) T_{t}+\tau\left(\frac{M_{t+1}-M_{t}}{M_{t}}-i(1-\tau)\right) M_{t}
$$

From (12) Sørensen directly concludes that the new shareholder tax ”... leaves no advantage from deferring the capital gains tax by postponing the realization from one period to the next”, since “...the postponed tax liability from the previous period is carried forward with interest”. 10

To penetrate the meaning of equation (12), we may assume that the investor who sells the asset in period $t$ also immediately buys it back. Suppose moreover that the capital gains tax, $T_{t}$ as defined above, is financed by a loan which is repaid in the next period, including interest. Net of this repayment, the after-tax wealth of the investor at the end of period $t+1$ is

$$
W_{t+1}^{R}=M_{t+1}-\tau\left(M_{t+1}-M_{t}(1+i(1-\tau))\right)-\tau\left(M_{t}-B_{t}\right)[1+i(1-\tau)],
$$

since the basis of the share when bought back in period $t, M_{t}$, is stepped up by the after-tax interest rate, for capital gains taxation in period $t+1$. Collecting terms, (13) simplifies to

$$
W_{t+1}^{R}=M_{t+1}-\tau\left(M_{t+1}-B_{t}(1+i(1-\tau))\right)
$$

If the investor instead of selling and buying back at time $t$ chooses to keep the share until period $t+1$, his after-tax wealth will be

$$
W_{t+1}^{H}=M_{t+1}-\tau\left[M_{t+1}-(1+i(1-\tau)) B_{t}\right]
$$

which is exactly as in (13’). Holding on to the asset hence offers no advantage compared to selling and buying back at time $t$. The Norwegian shareholder tax is holding period neutral.

From (13), we also find that the end-of-period value of the investor's total payment of capital gains tax is

$$
\begin{aligned}
& \tau\left(M_{t+1}-M_{t}(1+i(1-\tau))\right)+\tau\left(M_{t}-B_{t}\right)[1+i(1-\tau)] \\
& \equiv \tau\left(\frac{M_{t+1}-M_{t}}{M_{t}}-i(1-\tau)\right) M_{t}+\tau\left(M_{t}-B_{t}\right)[1+i(1-\tau)],
\end{aligned}
$$

which is Sørensen's expression for the tax liability in period $t+1$, as derived above (eq. (12)).

\footnotetext{
${ }^{10}$ Ibidem
} 
Despite the holding period neutrality as demonstrated above, the Norwegian shareholder tax may still cause the investor to hold on to his investments in shares, rather than selling and investing in other assets outside the stock market. This potential lock-in effect crucially depends on whether or not the rate of return allowance is capitalized into the market values of shares.

Assume, as before, that a share with a market value of $M_{t}$ is sold in period $t$ and that the after-tax proceeds $M_{t}-\tau\left[M_{t}-B_{t}\right]$ are invested outside the stock market at the market interest rate, $i$. The after-tax wealth of the investor in the next period would then be ${ }^{11}$

$$
W_{t+1}^{R^{*}}=[1+i(1-\tau)]\left[M_{t}-\tau\left(M_{t}-B_{t}\right)\right] \equiv M_{t}[1+i(1-\tau)]-\tau\left(M_{t}-B_{t}\right)[1+i(1-\tau)],
$$

where the second term on the far right hand side is the first period capital gains tax, augmented with the after- tax interest rate.

If the investor instead chooses to keep the share until period $t+1$, his after-tax wealth will be

$$
\begin{aligned}
W_{t+1}^{H} & =M_{t+1}-\tau\left[M_{t+1}-(1+i(1-\tau)) B_{t}\right] \\
& \equiv M_{t}[1+i(1-\tau)]-\tau\left(M_{t}-B_{t}\right)[1+i(1-\tau)]+M_{t}(1-\tau)[g-i(1-\tau)],
\end{aligned}
$$

where $g \equiv M_{t+1} / M_{t}-1$ is the pre-tax rate of return on the asset. Comparing (16) and (17), we find that holding on to the investment in shares yields a higher end-of -period wealth, even when the pre-tax returns are equal, $g=i$. However, a low return on the equity investment could outweigh the tax savings from the rate of return allowance. The implications of different shareholder tax regimes for before-tax rates of return have already been examined in previous section, on the assumption that the tax rules were capitalized into the market value of shares. In Regime 4 - the Norwegian shareholder tax - the before-tax rate of return required to make the investor indifferent to extending the holding period $L$ was found to be the after-tax rate of interest, $i(1-\tau)$ (see equation (9)). Not surprisingly then, for $g=i(1-\tau)$, expressions (16) and (17) are equal, implying indifference between realization (followed by investment outside the equity market, as in equation (16) above) and holding.

In summing up, we have confirmed Sorensen's claim that the Norwegian shareholder tax implies holding period neutrality. Unless the rate of return allowance is fully capitalized into

\footnotetext{
${ }^{11}$ The same result is obtained if the investor, as in (13) above, borrows to pay the capital gains tax.
} 
the market value of shares (such that the pre-tax equilibrium return equals the after-tax interest rate), there will still be a lock-in effect favoring equity investments in the corporate sector to investments in other sectors of the economy.

\section{The shareholder tax in a small open economy}

We conclude from the previous sections that the Norwegian shareholder tax might well eliminate the inefficiencies caused by the combination of corporate and personal taxes, provided that shareholder taxes are capitalized into the market values of companies. However, and as implied by earlier research by Boadway and Bruce (1992), Devereux and Freeman (1995) and others, the outcome may be different in a small open economy, where the marginal investor no longer is a domestic person entitled to the rate of return allowance.

When the rate of return requirement on corporate equity before personal taxes is determined by international investors on world capital markets, the earlier research has shown that any tax distortions to the cost of capital of domestic firms will remain in place, independently of the tax treatment afforded domestic investors. Changes in personal taxes on equity returns may affect domestic savings and the allocation of savings between alternative uses, but have no effect on the level of real investment.

In this section, we focus on the savings incentives in the open economy by comparing the after-tax returns received by the domestic shareholder in each of the four regimes examined in Section 2. For this open economy case, we let the before-tax return be equal to the market interest rate, $i$. To simplify the analysis, we consider an investment in shares with a dividend yield of $u$ and a rate of appreciation of $i$ - $u$. As before, we do not allow for risk.

The approach is straight-forward. For each regime $j=R 1, R 2, R 3$ and $R 4$, we compute the after-tax value of the investment, $W_{n}^{j}$, if sold in period $n$, and the after-tax dividend, $\operatorname{Div}_{n}^{j}$. We then define the after-tax rate of return received by the investor from marginally extending the holding period as $R_{n}^{j} \equiv \frac{\frac{\partial W_{n}^{j}}{\partial n}+D i v_{n}^{j}}{W_{n}^{j}}$, and the effective tax rate as the wedge between the pre-tax return and the after-tax return, divided by the pre-tax rate of return, i.e. $t^{j}=\frac{i-R_{n}^{j}}{i}$.

For Regime 1, which we include as a benchmark, we let both dividends and the accruing changes in the market value of the asset be taxed at the rate $\tau$. An investment of unit value at 
time zero, with a rate of appreciation of $i-u$ then has an after-tax value of $W_{n}^{R 1}=e^{(i-u)(1-\tau) n}$ at time $n$. Since the after-tax dividend is $u(1-\tau) e^{(i-u)(1-\tau) n}$, the after-tax rate of return from extending the holding period is

$$
R_{n}^{R 1} \equiv\left[\left(\partial W_{n}^{R 1} / \partial n\right)+u(1-\tau) e^{(i-u)(1-\tau) n}\right] / W_{n}^{R 1}=i(1-\tau)
$$

with the effective tax rate

$$
t^{R 1}=\frac{i-R_{n}^{R 1}}{i}=\tau
$$

Regime 2 is a conventional system of shareholder taxation, where the capital gain is taxed upon realization. The after-tax value of the investment if sold at time $n$ is then $W_{n}^{R 2}=e^{(i-u) n}-\tau\left[e^{(i-u) n}-1\right]$. Hence, the after-tax return from extending the holding period is

$$
R_{n}^{R 2} \equiv\left[\left(\partial W_{n}^{R 2} / \partial n\right)+u(1-\tau) e^{(i-u) n}\right] / W_{n}^{R 2}=\frac{i(1-\tau)}{1-\tau\left[1-e^{-(i-u) n}\right]},
$$

and the effective tax rate becomes

$$
t^{R 2}=\frac{\tau}{e^{(i-u) n}(1-\tau)+\tau}
$$

Hence, with a conventional realization-based capital gains tax, the after-tax return received by the investor and the implied effective tax rate depend on the holding period, see Figure 1.

For Regime 3, that is the Auerbach-Bradford tax scheme, we impose a tax rate of $\left[1-e^{-i \tau n}\right]$ upon both dividends and the sale of the asset. The after-tax dividend is then $u e^{(i-u) n}-\left[1-e^{-i \tau n}\right] u e^{(i-u) n}=u e^{-(i(1-\tau)-u) n}$ and the after-tax value of the asset $W_{n}^{R 3}=e^{(i-u) n}-\left[1-e^{-i \tau n}\right] e^{(i-u) n}=e^{(i(1-\tau)-u) n}$. The after-tax rate of return on extending the holding period is therefore

$$
R_{n}^{R 3} \equiv\left[\left(\partial W_{n}^{R 3} / \partial n\right)+u e^{-(i(1-\tau)-u) n}\right] / W_{n}^{R 3}=i(1-\tau),
$$

with the effective tax rate

$$
t^{R 3}=\tau .
$$


Finally, Regime 4 is the Norwegian shareholder tax. We assume first that $u \geq i(1-\tau)$, which means that dividends exceed the rate of return allowance throughout the holding period. The after-tax dividend is then $u e^{(i-u) n}-\tau\left[u e^{(i-u) n}-i(1-\tau)\right] \equiv(1-\tau) u e^{(i-u) n}+\tau i(1-\tau)$, and the after-tax value of the asset if sold at time $n$ becomes $W_{n}^{R 4}=e^{(i-u) n}-\tau\left[e^{(i-u) n}-1\right]$.

The after-tax return from extending the holding period is therefore

$$
\begin{aligned}
R_{n}^{R 4} & \equiv\left[\left(\partial W_{n}^{R 4} / \partial n\right)+(1-\tau) u e^{(i-u) n}+\tau i(1-\tau)\right] / W_{n}^{R 4} \\
& =i(1-\tau) \frac{\left[1+\tau e^{-(i-u) n}\right]}{\left[1-\tau\left[1-e^{-(i-u) n}\right]\right]}
\end{aligned}
$$

and we get the effective tax as

$$
t^{R 4}=\frac{\tau^{2}}{e^{(i-u) n}(1-\tau)+\tau}
$$

As in Regime 2, it is clear that the after-tax return received by the investor and the effective tax rate depend on the holding period, see Figure 1.

In case no cash dividends are paid during the holding period, that is $u=0$, the investor saves the rate of return allowance, including compound interest, until the asset is sold. The after tax value of the asset at time $n$ is then $W_{n}^{R 4}=e^{i n}-\tau\left[e^{i n}-e^{i(1-\tau) n}\right]$, considering that the cost base of the share now is $e^{i(1-\tau) n}$. The after-tax return from extending the holding period is therefore

$$
R_{n}^{R 4^{*}} \equiv\left[\left(\partial W_{n}^{R 4} / \partial n\right)\right] / W_{n}^{R 4}=i(1-\tau) \frac{\left[1+\tau e^{-i \tau n}\right]}{\left[1-\tau+\tau e^{-i \tau n}\right]},
$$

and we get the effective tax as

$$
t^{R 4^{*}}=\frac{\tau^{2}}{e^{i \tau n}(1-\tau)+\tau}
$$

We note that for $u=i(1-\tau)$, expressions (24) and (25) turn into expressions (24') and (25').

In summing up, we have found that with an exogenously determined pre-tax rate of return, only Regime 1 (with an accruals based capital gains tax) and Regime 3 (the Auerbach- 
Bradford capital gains tax) yield after-tax returns that are independent of the holding period and effective tax rates that equal the statutory capital income tax rate. These regimes hence offer no tax incentives to extend the holding period, or to reallocate savings from interest bearing assets into corporate equity.

In contrast, for Regime 2 (with a realization based capital gains tax) and Regime 4 (the Norwegian shareholder tax), the shareholder receives considerably higher after-tax returns, and the implied effective tax rates are much below the statutory tax rate. In case of Regime 2, this is driven by the possibility to defer capital gains tax until realization, while for Regime 4, the lenient tax treatment derives from the rate of return allowance. Moreover, and as is clear from expressions (21) and (25), the effective tax rate for Regime 4 is only $\tau$ times that of Regime 2. Because of this, we conclude that the Norwegian shareholder tax distorts the allocation of savings between interest bearing assets and corporate shares more than does conventional shareholder taxation with a realization-based capital gains tax.

To further clarify our results, we have also computed after-tax returns and effective tax rates for different holding periods in Figures 1 and 2. We have set the pre-tax rate of return $i$ to 5 percent and we assume that the capital income tax rate $\tau$ is 30 percent. The computations have been carried out for two alternative assumptions for the dividend yield. The first assumes that the asset does not generate any cash flows until sold at time $n, u=0$, and the other that the dividend yield equals the after-tax interest rate, $u=i(1-\tau)$. Distinguishing between assets with different dividend yields turns out to be of importance only for Regime 2 (with a conventional realization-based capital gains tax).

For Regime 2, the shareholder will also markedly raise his after-tax marginal return and reduce the effective tax rate by extending the holding period. The force of this effect depends inversely on the dividend yield: The lower is the dividend yield, the less of the asset's pre-tax return is taxed as it accrues, and the more is taxed upon the sale of the asset. There is hence a double lock-in effect, favoring both an extension of the holding period and investments in corporate shares with a low pay-out rate. Regime 4, the Norwegian shareholder tax, likewise offers a time-increasing incentive for the shareholder to hold on to his investment in corporate 
equity, but this effect is much less pronounced than for Regime 2, and is also insensitive to the assumed dividend-yield ${ }^{12}$.

\footnotetext{
${ }^{12}$ This holds in the range $0 \leq u \leq i(1-\tau)$. For $u>i(1-\tau)$, the curve for the effective tax rate, $t^{R 3^{*}}$, flattens out
} as $u$ rises, to be constant and equal to $\tau^{2}$ for $u=i$. 
Figure 1. After-tax rate of return

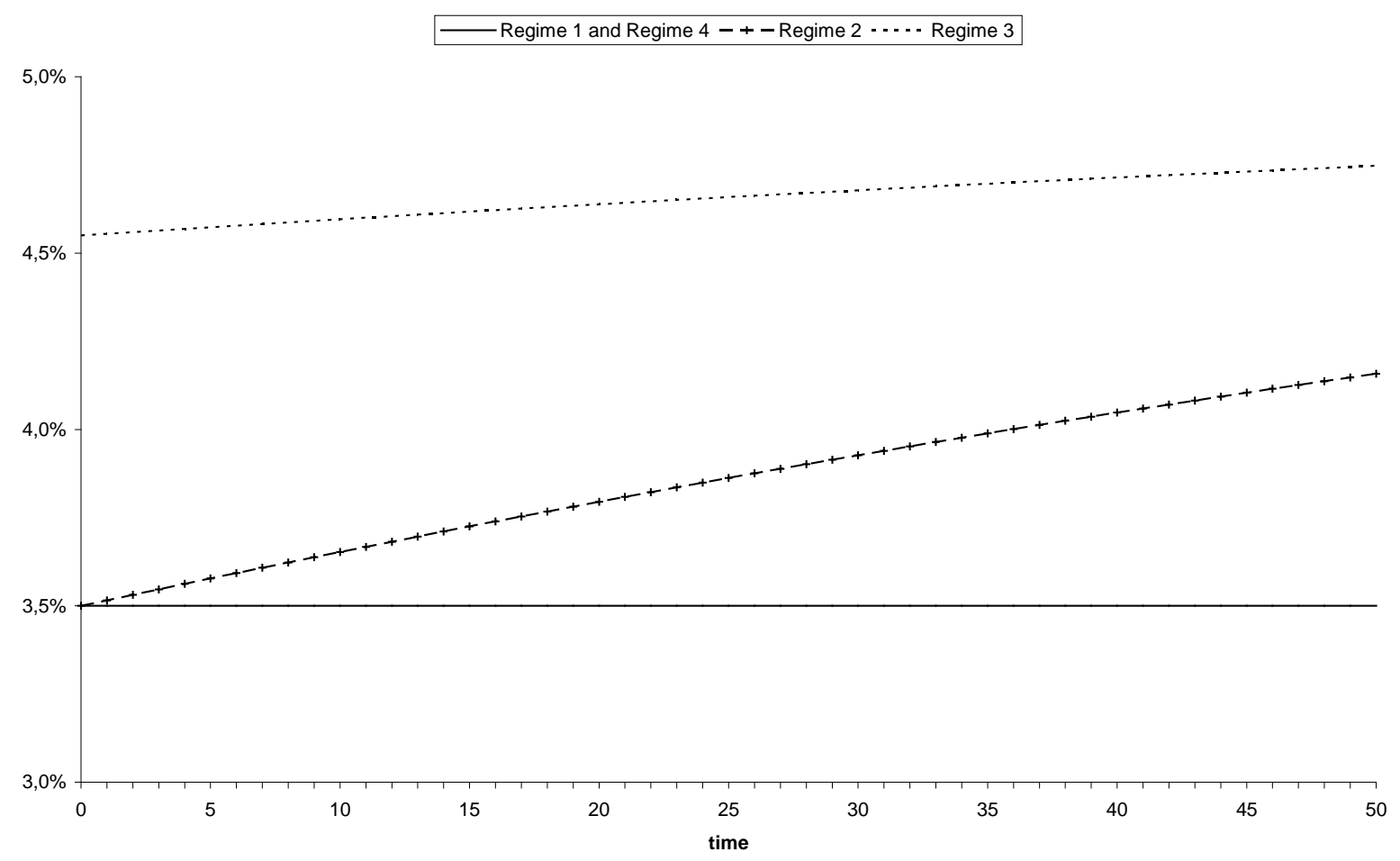

Figure 2. The effective tax rate

— Regime 1 and Regime 4 - + Regime 2 - . - . Regime 3

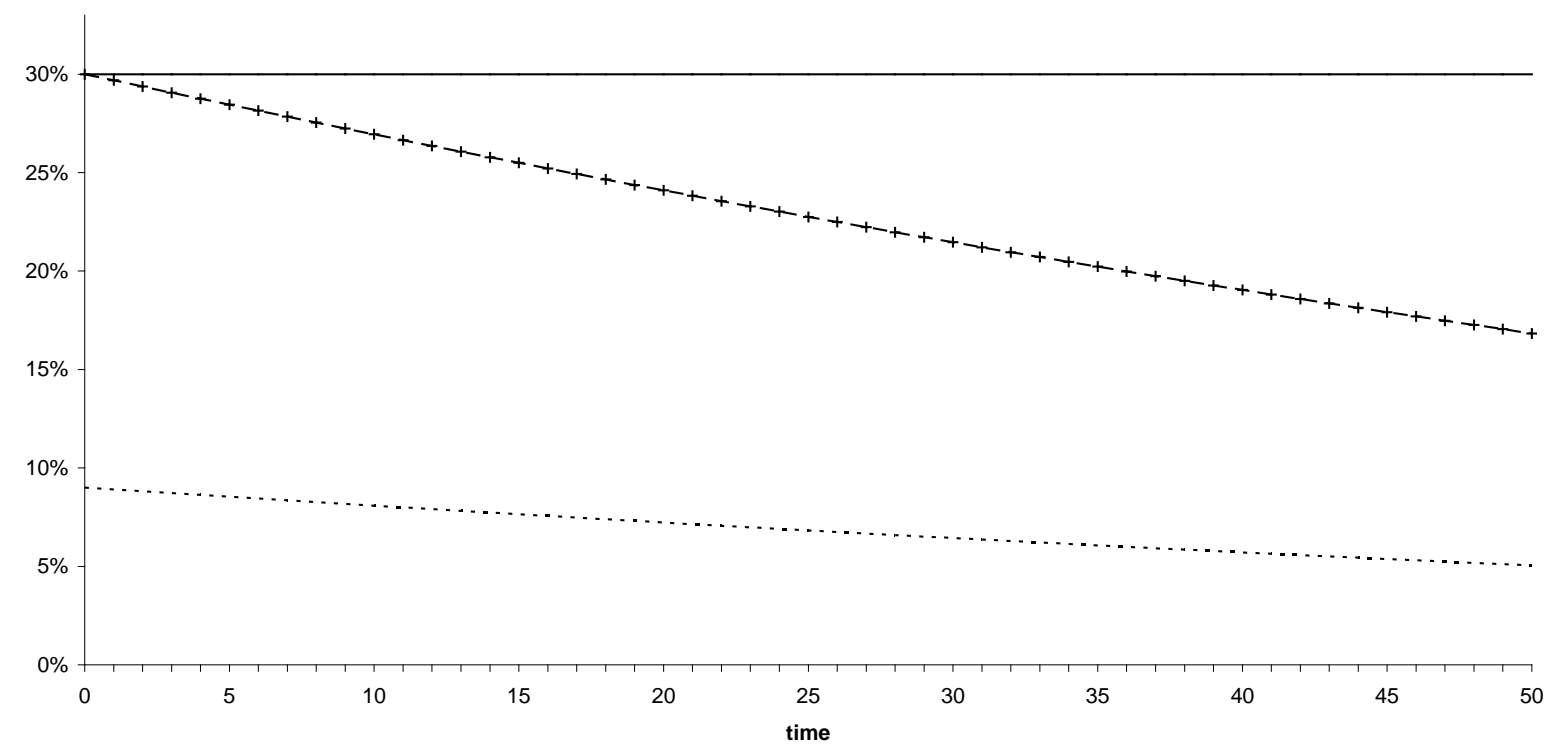




\section{Small versus large firms}

Though internationalization has made it possible for firms in small open economies to finance their investments on the international markets for equity, such options may be unevenly distributed between firms. It has been argued that small firms, in particular, still are confined to raising equity funds from domestic investors and, because of this, would benefit from a mitigation of double taxation at the shareholder level. ${ }^{13}$ Apel and Södersten (1999), address this possibility in their investigation of the effects of personal taxes on the cost of capital in a small open economy. Apel and Södersten use a simple portfolio model where investors are assumed to hold three assets, i.e. risk-free bonds, shares in large firms and shares in small firms with uncertain returns. Shares in large corporations are traded in the international stock market, implying that the (pre-personal tax) rates of return are exogenously given to the national economy. Small company shares, in contrast, are traded only domestically and the authors' problem is to determine the impact of taxation on the required (pre-personal tax) rate of return on these shares, that is, the (after-corporate tax) cost of capital. The Apel-Södersten model is easily extended to capture also the effects of the Norwegian shareholder tax.

Though the interested reader may consult the Apel-Södersten paper for the derivation of the model, the basic equations have a sufficiently strong intuitive appeal to justify that we focus directly on the results. The representative domestic investor acquires $q_{s}$ small company shares and $q_{L}$ shares in large companies, at initial prices of $P_{S 0}$ and $P_{L 0}$.With $R_{B}$ as the pretax rate of return on bonds, and $\tau_{E}$ and $\tau_{B}$ as the personal tax rates on the return to equity and bond interest, respectively, the authors find that the expected pre-tax required rates of return ${ }^{14}$ on shares in small $(S)$ and large $(L)$ firms may be written as

$$
\begin{array}{ll}
R_{S}=R_{B}\left(\frac{1-\tau_{B}}{1-\tau_{E}}\right)+C\left(1-\tau_{E}\right) \frac{\left(q_{S} \sigma_{S}^{2}+q_{L} \sigma_{S L}\right)}{P_{S 0}}, & \text { A-S, equation (2) } \\
R_{L}=R_{B}\left(\frac{1-\tau_{B}}{1-\tau_{E}}\right)+C\left(1-\tau_{E}\right) \frac{\left(q_{L} \sigma_{L}^{2}+q_{S} \sigma_{S L}\right)}{P_{L 0}}, & \text { A-S, equation (3) }
\end{array}
$$

\footnotetext{
${ }^{13}$ For further discussion, see Agell et. al. (1998), Chapter 4.

${ }^{14}$ Note the definition $R_{i} \equiv \frac{P_{i 1}-P_{i 0}}{P_{i 0}}, i=S, L$, where $P_{i 1}$ is the expected end -of -period price.
} 
where $\mathrm{C}$ (a constant) is a measure of the investor's risk tolerance, $\sigma_{i}^{2}(i=L, S)$ is the variance of the end-of-period prices and $\sigma_{L S}$ is the covariance between the end-of period prices of shares in small and large firms. Hence, by solving the investor's portfolio problem Apel and Södersten find that the expected before-personal-tax required return equals the before-tax return on risk-free bonds plus a risk premium, the seize of which depends on the investor's risk tolerance, measured by $C$, multiplied by the amount of risk that the shares add to the investor's portfolio. This amount depends on both the own variance and on the covariance between the prices of small and large company shares.

The Norwegian shareholder tax is easily incorporated into these expressions. The tax due on the return (represented by an increase in the market prices) on shares of the $i$ :th type is

$\tau_{E}\left[q_{i}\left(P_{i 1}-P_{i 0}\right)-\eta_{i} R_{B}\left(1-\tau_{B}\right) q_{i} P_{i 0}\right]$

where the second term within brackets captures the rate of return allowance. The parameter $\eta_{i}$ (which is unity when the allowance is in effect, and zero otherwise) is included to distinguish between the case with a general allowance $\left(\eta_{S}=\eta_{L}=1\right)$, and the case where the allowance is limited to, say, small firms (in this case $\eta_{S}=1, \eta_{L}=0$ ). The expected returns, as shown above, now changes to

$$
\begin{aligned}
& R_{S}=R_{B}\left(\frac{1-\tau_{B}}{1-\tau_{E}}\right)+C\left(1-\tau_{E}\right) \frac{\left(q_{S} \sigma_{S}^{2}+q_{L} \sigma_{S L}\right)}{P_{S 0}}-\eta_{S} \tau_{E} R_{B}\left(\frac{1-\tau_{B}}{1-\tau_{E}}\right), \\
& R_{L}=R_{B}\left(\frac{1-\tau_{B}}{1-\tau_{E}}\right)+C\left(1-\tau_{E}\right) \frac{\left(q_{L} \sigma_{L}^{2}+q_{S} \sigma_{S L}\right)}{P_{L 0}}-\eta_{L} \tau_{E} R_{B}\left(\frac{1-\tau_{B}}{1-\tau_{E}}\right) .
\end{aligned}
$$

Following Apel and Södersten, we treat the expected return on large company shares, $R_{L}$, and the number of small company shares, $q_{S}$, as exogenous. As a result of this, the adjustment to a tax change, in the case of large firms, will take the form of a change in the number of shares, $q_{L}$, which the investor chooses to hold. We derive from (28)

$$
q_{L}=\frac{P_{L 0}\left[R_{L}-R_{B}\left(\frac{1-\tau_{B}}{1-\tau_{E}}\right)+\eta_{L} \tau_{E} R_{B}\left(\frac{1-\tau_{B}}{1-\tau_{E}}\right)\right]-C\left(1-\tau_{E}\right) q_{S} \sigma_{S L}}{C\left(1-\tau_{E}\right) q_{S} \sigma_{L}^{2}} .
$$


The intuitively clear answer given by the model is that the higher is the expected before-tax return on large company shares, the higher will be the number of large company shares in the investor's portfolio (the number of risk-free bonds smaller). A rate of return allowance for large company shares (as captured by the parameter $0 \leq \eta_{L} \leq 1$ ) also induces the investor to hold a greater number of large company shares ${ }^{15}$.

Using expression (29) to substitute for $q_{L}$ in (27), we get the expected before-tax return on small company shares

$$
\begin{aligned}
R_{S}= & R_{B}\left(\frac{1-\tau_{B}}{1-\tau_{E}}\right)\left[1-\eta_{S} \tau_{E}-\frac{P_{L 0}}{P_{S 0}} \frac{\sigma_{S L}}{\sigma_{L}^{2}}\left(1-\eta_{L} \tau_{E}\right)\right]+R_{L} \frac{P_{L 0}}{P_{S 0}} \frac{\sigma_{S L}}{\sigma_{L}^{2}} \\
& +C\left(1-\tau_{E}\right) \frac{q_{S} \sigma_{S}^{2}}{P_{S 0}}\left[1-\left(\frac{\sigma_{S L}}{\sigma_{S} \sigma_{L}}\right)^{2}\right]
\end{aligned}
$$

It is immediately clear from (30) that, by increasing the after-tax rate of return, a rate of return allowance available to small firms $\left(\eta_{S}>0\right)$ will reduce the pre-tax required rate of return on small company shares, $R_{S}$. Conversely, a rate of return allowance on large company shares ( $\eta_{L}>0$ ) will increase $R_{S}$. As seen from (30), the balance between these opposing effects depends on the factor $\frac{P_{L 0}}{P_{S 0}} \frac{\sigma_{S L}}{\sigma_{L}^{2}}$. It is straightforward to show that

$$
\frac{P_{L 0}}{P_{S 0}} \frac{\sigma_{S L}}{\sigma_{L}^{2}}=\frac{\operatorname{cov}\left(R_{S}, R_{L}\right)}{\operatorname{var}\left(R_{L}\right)} \equiv \beta,
$$

which has an interesting interpretation as the "beta” between the returns on shares in small and large firms. Using this definition of "beta" and assuming that the rate of return allowance is available to small and large firms alike, $\eta_{S}=\eta_{L}=\eta$, equation (30) simplifies to

$$
R_{S}=R_{B}\left(\frac{1-\tau_{B}}{1-\tau_{E}}\right)\left(1-\eta \tau_{E}\right)[1-\beta]+R_{L} \beta+C\left(1-\tau_{E}\right) \frac{q_{S} \sigma_{S}^{2}}{P_{S 0}}\left[1-\left(\frac{\sigma_{S L}}{\sigma_{S} \sigma_{L}}\right)^{2}\right]
$$

\footnotetext{
${ }^{15}$ Since the number of small company shares $q_{s}$ is exogenously given, this means that the total number of risky assets $\left(q_{L}+q_{S}\right)$ in the investor's portfolio will rise.
} 
Equation (32) shows the crucial role played by "beta", that is the covariance between the returns on small and large company shares. The higher is "beta", the stronger is the impact of the internationally determined rate of return, $R_{L}$, and the smaller is the effect of the rate of return allowance, $\eta$, on $R_{S}$. For "beta" equal to unity, the allowance is of no importance, and with "beta" above unity, the allowance will actually raise the expected pre-tax return on small company shares.

The impact of the rate of return allowance on the required pre-tax rate of return on small company shares is hence an empirical question, depending on "beta". For illustrative purposes, we have computed beta-values in accordance with expression (31), using monthly data on two groups of companies noted on Nordic stock exchanges during the period 2004 to 2010. Depending on data availability ${ }^{16}$, two different sets of calculations have been undertaken, reported in panels a) and b) in Table 2. The group of small companies is represented by a so-called Small Cap index as defined by the Stock Exchange of each country, typically representing the 10 percent smallest companies noted on the market.

Table 2. The Beta value between small and large companies, monthly data for different time periods.

\begin{tabular}{|c|c|c|c|c|c|}
\hline $\begin{array}{l}\text { a) Small companies against the largest, } \\
\text { most traded companies (about 25-30) }\end{array}$ & & $1990-93$ & $1994-97$ & 2004-06 & $2007-10$ \\
\hline Sweden, Apel and Sodersten (1999) & & 0,69 & 1,04 & & \\
\hline Sweden & & & & & 0,79 \\
\hline Norway & & & & 1,04 & 0,74 \\
\hline Nordic countries & & & & & 0,80 \\
\hline $\begin{array}{l}\text { b) Small companies against a } \\
\text { benchmark index of larger companies }\end{array}$ & \# large & & & 2004-06 & 2007-10 \\
\hline Sweden & $80-100$ & & & & 0,77 \\
\hline Norway & all & & & 1,04 & 0,83 \\
\hline Finland & $50-70$ & & & & 0,90 \\
\hline Denmark & $50-80$ & & & & 0,74 \\
\hline
\end{tabular}

In panel a), the group of large companies is represented by an index of the 25-30 most traded shares on the Swedish and Norwegian markets separately, as well as the most traded companies on the whole of the Nordic market. Although covering different time periods, the results obtained in Apel and Södersten (1999) are also reported for comparison. In panel b), we have made use of a so-called benchmark index of large companies as defined by the Stock Exchanges. This is a broader index, counting for 50-100 companies, that is available for all Nordic countries separately (Iceland is left out due to too few observations).

\footnotetext{
${ }^{16}$ Data is collected from the Nasdaq OMX Nordic's web page (covering Sweden, Denmark and Finland) and the Oslo Stock Exchange's web page (covering Norway), where historical data is more comprehensive for Norway.
} 
Judging from the various estimates of "beta" reported in Table 2 - with the magnitude in the range of $0.7-1.0$, independently of market and time period - we tentatively conclude that the internationally determined rate of return requirement on large company shares may have a very substantial impact on the rate of return requirement for small company shares. Such a link considerably weakens any positive effect that the rate of return allowance may have for small domestically owned companies. Moreover, the case where "beta" is equal to unity or higher - implying a detriment effect of the Norwegian rate of return allowance system - may not be just a theoretical curiosity.

\section{Conclusions}

In this article, we confirm Sørensen’s (2005) result that the Norwegian shareholder tax will be neutral towards financing and investment decisions. However, this requires the strong assumption that a full capitalization of the rate of return allowance occurs. Considering that Norway is a small open economy with an extensive foreign ownership of corporate shares, a more appropriate assumption seems to be that the before-tax equilibrium rate of return is determined by international investors ${ }^{17}$. Any distortions to the cost of capital created by the corporate income tax will then remain in place, independently of the tax treatment afforded domestic investors.

The rate of return allowance of the Norwegian shareholder tax, which only benefits domestic shareholders, may still affect domestic savings and the allocation of savings between alternative uses. As verified in Section 3 above, the shareholder tax is holding period neutral in the sense that holding on to a corporate share offers no tax advantage compared to selling and re-investing in the stock market. But the shareholder tax does offer an incentive for the shareholder to hold on to his investment in corporate equity compared to investing outside the stock market, when the pre-tax rate of return on shares is determined on international markets. Because of this lock-in effect, the Norwegian shareholder tax distorts the allocation of savings more (for a given statutory tax rate) than does a conventional tax regime with a realization based capital gains tax.

It has been argued in the public debate that a mitigation of double taxation at the shareholder level still may affect the cost of capital in an open economy, because small companies have

\footnotetext{
${ }^{17}$ Bond, Devereux and Klemm (2007) present evidence which is consistent with the assumption that no capitalization of personal taxes on dividends occurs in small open economies.
} 
limited access to international equity markets. To consider this possibility, we have briefly presented a simple portfolio model with small and large firms. The effect of the rate of return allowance on the small company cost of capital then turns out to depend on the "beta" between the returns on small and large company shares. Our tentative estimates of "beta", using data from Nordic stock exchanges, indicate that the internationally determined rate of return requirement on large company shares may have a very substantial impact on the rate of return requirement for small company shares. Such a link considerably weakens the effect of the rate of return allowance also for small domestically owned companies, and may even imply a detrimental effect on small company investment incentives.

The main reason for the adoption of the Norwegian shareholder tax was mounting problems of tax avoidance under the earlier imputation system. Under the new scheme, the incentive for income shifting is considerable reduced, since any withdrawal of money in excess of the rate of return allowance is double taxed - through the combination of the corporate income tax and the personal tax on income from capital. Obviously, a classical corporate tax system with no mitigation of double taxation at the shareholder level is equally effective in this respect, and would - in the small open economy - distort shareholders’ portfolio decisions considerably less, without worsening companies' incentives for real investment. However, to the extent that the government wants to promote real investment in small companies, there may still be a role for a rate of return allowance at the shareholder level. This requires, as we demonstrated in section 5, that the allowance be targeted to this group of domestically owned companies. Whether this could be achieved without opening up new forms of tax arbitrage is of course a crucial question. 


\section{References}

Agell, J., Englund P. and Södersten, J. (1998), Incentives and Redistribution in the Welfare State, the Swedish Tax Reform, MacMillan Press, 1998.

Andersson, K., Kanniainen,V., Södersten,J. and Sørensen, P. B. (1998), “Corporate Tax Policy in the Nordic Countries”, in P.B. Sørensen, ed, Tax Policy in the Nordic Countries, MacMillan Press, 1998.

Apel, M. and Södersten, J. (1999), "Personal Taxation and Investment Incentives in a Small Open Economy”, International Tax and Public Finance, vol. 6(1), pp. 79-88, January.

Auerbach, A. (1991), “Retrospective Capital Gains Taxation”, American Economic Review, vol. 81, pp. 167-178.

Auerbach, A. and Bradford, D. (2004), “Generalized cash-flow taxation”, Journal of Public Economics, vol. 88 (5), pp. 957-980, April.

Boadway, R. and Bruce, N. (1992), "Problems with integrating corporate and personal income taxes in an open economy", Journal of Public Economics, vol. 48(1), pp. 39-66, June.

Bond, S., Devereux, M. and Klemm, A. (2007), “The Effects of Dividend Taxes on Equity Prices: A Re-Examination of the 1997 UK Tax Reform”, Oxford University Centre for Business Taxation, WP 07/01.

Devereux, M. and Freeman, H. (1995), "The impact of tax on foreign direct investment: Empirical evidence and the implications for tax integration schemes," International Tax and Public Finance, vol. 2(1), pp. 85-106, February.

Johansson, S-E (1961), Skatt, Investering, Värdering, Norstedt, 1961. (in Swedish)

Samuelson, P. A. (1964), “Tax Deductibility of Economic Depreciation to Insure Invariant Valuations”, Journal of Political Economy 72, pp.604-606.

Sinn, H-W (1987), Capital Income Taxation and Resource Allocation, North-Holland, 1987.

Sørensen, P. B. (2005), “Neutral Taxation of Shareholder Income”, International Tax and Public Finance 12(6), pp. 777-801, November. 